\section{Legasov's indictment of Chernobyl management}

\section{- Senior atomic scientist commits suicide}

\section{- "Lessons" still to be learned}

\section{London}

THE Chernobyl disaster was the "apotheosis and peak of the economic mismanagement in our country over decades", dictated Academician Valerii Legasov, shortly before he took his own life last month. Legasov, chief deputy director of the Kurchatov nuclear energy institute, had been one of the first scientists to visit Chernobyl after the accident, and in September 1986 headed the Soviet team at the post-accident conference convened by the International Atomic Energy Agency (IAEA) in Vienna.

Last year, Pravda asked Legasov for his personal recollections of the accident, of the clean-up and for his thoughts on the future of nuclear power. His notes appeared in Pravda last week, filling almost a page and a half - the sort of coverage normally devoted only to major party declarations.

Legasov, whom Pravda describes as "simultaneously a Don Quixote and a Joan of Arc", was clearly worried about the safety of nuclear reactors long before the accident. The notes cite the practice in the United States of making "systematic assessments of the probability of every type of accident", saying that there was not a single team in the Soviet Union with "even the slightest competence" to pose and solve such problems.

Even the best of the scientists working on nuclear safety, V.A. Sidorenko, concentrated, Legasov said, on organizational methods of dealing with incidents and better documentation systems for power station constructors and operators. The top personnel of the nuclear industry became older and more set in their ways, new approaches were unwelcome and suggestions that there should be a new approach to safety met with increasing hostility. Reactor builders did indeed consider the RBMK (the reactor type installed at Chernobyl) unsatisfactory, but only because of its high cost and fuel consumption, not for reasons of safety.

Even the directors of nuclear power stations seemed oblivious of danger. "What are you so worried about?", one of them asked Legasov. "An atomic reactor is only a samovar, it is much simpler than a thermal station, we have experienced personnel and nothing is going to happen, never!"

At 1.24 a.m. on 26 April 1986, however, the impossible happened. By the afternoon of the same day, Legasov was in
Kiev, where he found the leaders of the Ukrainian SSR in a state of alarm but with no precise information other than that "things are bad". There was considerable confusion over such vital matters as respirators, and radiation meters (both of which were in short supply) and there were no leaflets available for distribution to the population setting out in simple terms the dos and don'ts of radiation hygiene. The fire-fighting operations were equally badly organized, it appears. Legasov notes that for lack of adequate ground support, helicopter pilots had themselves to load sandbags before flying them in to dump on the burning reactor.

The immediate cause of the Chernobyl accident, the government commission found, was the decision to go ahead with

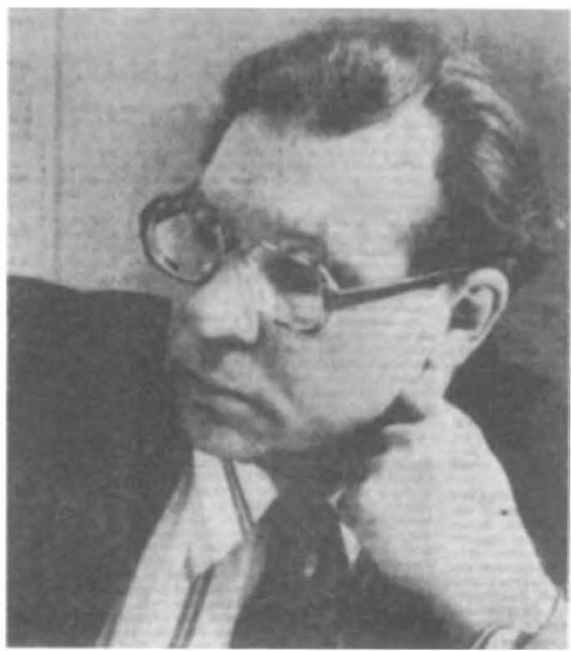

Valerii Legasov as pictured in Pravda another Chernobyl victim?

an experiment on the rotors, under conditions when it was no longer safe, and also the unauthorized disconnection of the safety systems to make this feasible. But, Legasov concluded, when one considered the whole chain of circumstances, the mistakes and attitudes which surrounded the accident, it was impossible to point to one particular person or decision as the guilty party or the cause of the disaster.

"The lessons of Chernobyl have still not been analysed to the end", Legasov told Pravda just before he took his life.

Whether this statement had any connection with his death is unclear - Pravda revealed the fact of his suicide not the motive. But his final article, to which Pravda gave the title "It is my duty to speak out", may well lead to the "lessons" being re-examined.

\section{IAEA's verdict on Chernobyl}

\section{Vienna}

Cucumbers grown in sontaminated soil from the Chernobyl art $\alpha$ were sampled by a delegation from the International Atomic Energy Agency (IAEA) visiting the Soviet power plant last week. The visit coincided with a conference in Kiev on medical aspects of the Chernobyl accident.

IAEA director-general Hans Blix and his companions ate cucumbers and radishes that had been grown in contaminated soil in a greenhouse in Pripyat, a few kilometres from Chernobyl. Researchers there are testing a variety of plants to determine how much radioactive caesium and other elements they take up. They are also seeking useful mutations resulting from the radiation. Blix said that the cucumbers and radishes were among plants that did not absorb much caesium.

According to one IAEA official, the conference was told that, on the basis of a study of 30,000 people living in the area, no adverse health effects on the general population had been attributed to the radiation. It is known that 31 people died in the accident and more than 200 suffered radiation sickness. The recently expanded Centre for Radiation Medicine in the suburbs of Kiev plans to continue its search for long-term effects of the radiation on 600,000 people who were exposed.

The IAEA team reported several changes since its last visit in January 1987. Another reactor had been returned to service, immediately adjacent to the concrete-encased reactor, in which the temperature has dropped from $106^{\circ} \mathrm{C}$ to $36^{\circ} \mathrm{C}$. Large-scale soil decontamination continues within a $30 \mathrm{~km}$ radius

Plans to build two more reactors at Chernobyl have been shelved, said Blix. More than 1,000 elderly villagers have returned illegally to 20 villages in the $30-\mathrm{km}$ zone, but the authorities will apparently allow them to stay. The Soviet government seems to consider the residual radiation less of a risk to these people's health than the continuing separation from their homes. Although there are still a few hot spots, most of the area within 10 to $30 \mathrm{~km}$ from the reactor has returned to normal levels of radioactivity.

A recent and highly unusual report in Pravda, had criticized the managers at the plant for hiring unqualified workers; Blix said that the Soviets had confirmed the report but that plant operators had not been affected. The unqualified personnel had been attracted by the high pay offered and the payrolls had become "swollen" with unskilled workers, said Blix.

Steven Dickman

The developing countries are seeking a bigger say in IAEA affairs. See page 288. 